\title{
Graptoloid cladistics, taxonomy and phylogeny
}

\author{
Jörg MALETZ, Jesse CARLucCi \& Charles E. MitChell
}

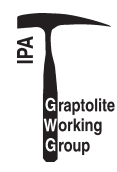

\begin{abstract}
A cladistic analysis aimed at understanding the phylogenetic relationships of basal (Early to Mid Ordovician) planktic graptolites resulted in a well-resolved majority rule consensus tree that displays a series of major monophyletic groups. This tree was used to produce a classification system for the planktic Graptoloida, one of the major groups of the Graptolithina. Resolution within the individual taxonomic units is low, however, as only few species of the individual groups were included in the analysis. Tree statistics such as the retention index show that the proximal end characters used in the analysis are more reliable indicators of synapomorphy, whereas distal rhabdosome characters show significantly more homoplasy on the consensus tree. This result supports previous qualitative assessments suggesting that the initial part of the colony appears to have been relatively conservative during the evolution of the graptolites, whereas the distal features are more easily modified. Thus, the proximal end structure is especially relevant for revealing shared common ancestry through the presence of distinct homologies. Based on the structure of the consensus tree, we recognize a series of nested holophyletic clades, primarily total clades (names of which are identified by the prefix Pan-) and crown clades. The proposed names conserve the traditional names applied to common graptolite higher taxa as much as possible and yet precisely describe the branching history of the clade. The Graptoloida is the clade that descended from the first graptolithine to possess a nematophorous sicula and planktic habit and comprises a stem lineage of "anisograptids" (e.g., Rhabdinopora flabelliformis and Anisograptus matanensis), plus the crown clade Supercohort Eugraptoloida. The Eugraptoloida includes all the remaining graptoloids, which form the sister taxa, Cohort Pan-Reclinata nov. and Cohort Pan-Sinograpta. Many familiar genera formerly included among the Dichograptidea form a stem lineage to the crown clade Subcohort Reclinata nov. The Reclinata includes the sister clades, Superorder Pan-Tetragrapta nov. and Superorder Pan-Bireclinata nov. The Pan-Bireclinata comprises stem group bireclinatids (including Isograptus) and the crown clade Order Bireclinata nov., which in turn consists of the sister total clades Suborder Pan-Glossograpta nov. and Suborder Pan-Axonophora nov. The Pan-Axonophora are represented in this analysis only by stem lineage species (Arienigraptus gracilis to Exigraptus uniformis), but the group contains the roots of the diverse and well-known diplograptids and monograptids, which dominate subsequent Middle Ordovician to Early Devonian graptolite faunas. - Key words: graptolites, Ordovician, phylogenetic taxonomy, cladistics, evolution, Eugraptoloida, Reclinata, Bireclinata.
\end{abstract}

Maletz, J., CARluCCI, J. \& Mitchell, C.E. 2009. Graptoloid cladistics, taxonomy and phylogeny. Bulletin of Geosciences 84(1), 7-19 (6 figures, 2 tables). Czech Geological Survey, Prague. ISSN 1214-1119. Manuscript received July 20, 2008; accepted in revised form November 10, 2008; published online December 10, 2008; issued March 31, 2009.

Jörg Maletz \& Charles E. Mitchell, Department of Geology, The University at Buffalo, SUNY, Buffalo, NY, 14260-3050, U.S.A.; jorgm@buffalo.edu, cem@nsm.buffalo.edu・Jesse Carlucci, The University of Oklahoma, College of Earth and Energy, School of Geology and Geophysics, 100 East Boyd Street Suite 810, Norman, OK 73019, U.S.A.; Jesse.R.Carlucci-1@ou.edu.

Many attempts at differentiating among the major groups within the graptolites have been undertaken over the years and various (sometimes even contradictory) taxonomic concepts exist. Early efforts to divide the group focussed on the number of stipes and their orientation (Lapworth 1873, Hopkinson \& Lapworth 1875), but the resulting taxa are now regarded as grades of organization ( $c f$. Jaeger 1978). Indeed, the conceptual basis for graptolite taxonomy has changed dramatically over time (Hall 1865; Frech 1897; Mu 1950, 1974, 1987; Yu \& Fang 1979; Bulman 1955, 1963, 1970; Rigby 1986). A unifying theme is the planktic habit of all graptolites included in the order Graptoloidea (Lapworth in Hopkinson \& Lapworth 1875). This opinion was supported by Fortey \& Cooper (1986), who provided the only comprehensive cladistic analysis on Lower Ordovician graptoloids and referred all forms with a free nema to an emended Graptoloidea, including the Anisograptidae (Bulman, 1950) with their close relationships to the benthic Dendrograptidae (Roemer in Frech, 1897). In recent decades, work has focused on defining graptoloid taxa by the use of characters of demonstrated phylogenetic significance (Fortey \& Cooper 1986, Mitchell 1987, Melchin 1998), but this approach has been used only in a few groups. Thus, the upper level classification is left in a state of transition. 
From a phylogenetic standpoint, the early colony growth or astogeny of the graptolites is comparable to the embryological history or ontogeny of an organism (Urbanek 1960, 1973, 2004), which suggests that graptoloids that share distinctive proximal end characters likely belong to a monophyletic group (Cooper \& Fortey 1982, 1983). As the astogenetic patterns are the evolutionarily most stable and conservative parts of the colony, a shared early developmental pattern among graptolites indicates their common descent (Mitchell 1986). Recent phylogenetic analyses of Early to Middle Ordovician graptoloids focused on these proximal characters (Fortey \& Cooper 1986, Maletz \& Mitchell 1996, Fortey et al. 2005, Mitchell et al. 2007) and provided an important step in understanding graptolite taxonomy and evolution. Carlucci (2008) conducted a quantitative cladistic analysis to understand the evolution of the early Graptoloidea and to provide a guide to early graptoloid classification. This work is the basis for the classification proposed herein, which we have constructed mindful of the value of retaining familiar names. We are also mindful of the need for a set of nested monophyletic taxa that correspond to the considerable diversity of the one of the principle descendents of the graptolites examined here, namely the Axonophora Frech, 1897 (approximately equivalent to the Diplograptina+Monograptina of Bulman 1970), and this awareness lead us to employ a set of relatively high and potentially unfamiliar ranks in the proposed classification.

\section{Materials and methods}

Isolated graptolite material from the Cow Head and Table Head groups of western Newfoundland demonstrates the enormous variation of proximal developments found in Lower Ordovician graptoloids and permits refinement of their classification. This material provides the database for the structural investigation and recognition of proximal rhabdosome characters for the cladistic analysis. Additional information comes from isolated graptolite material described in various publications.

A majority of described graptolite species are known from flattened specimens preserved in shale, but not from chemically isolated relief material and, thus detailed information on fusellar structure and rhabdosome growth is not available for these species. Because of these limitations, we used single species as proxies for each of the genera included in our analysis, and based the data for the matrix on material from a single sample/level in a particular locality. In many instances, the availability of isolated material was the determining factor in picking which taxa to use. We tried to select taxa that represent the full range of Early to Middle Ordovician graptoloids. The problem with this approach is that we had to sacrifice the resolution of the internal tree structure of the individual clades.
Our analysis emphasized proximal characters. We included a small number of continuous characters in our analysis based on the measurements of dimensions of the proximal ends. Using continuous characters allows for proximal geometry, shape, and proportions to be used in the analysis when no discrete states are recognizable. We used finite mixture coding (FMC) for the binning of continuous characters, following Strait et al. (1996) and carried out the required analyses using a program supplied by H.D. Sheets (personal communication, 2007).

The data set for the analysis consists of 32 ingroup taxa and 1 outgroup taxon (Rhabdinopora flabelliformis), 47 characters with a total of 116 states, of which 26 are binary and 21 are multi-state, 3 characters are ordered (Tables 1, 2 in appendix). These characters code morphologic features of the prosicula (4 characters), metasicula ( 8 characters), proximal development (16 characters), thecal morphology (6 characters), and rhabdosome structure (13 characters). Matrix construction was undertaken using MacClade v4.08 (Maddison \& Maddison 2005). The number of taxa involved made a Branch-and-Bound analysis computationally impossible for our data set. While not optimum because of the difficulty in finding true minimum length trees, we utilized heuristic parsimony searches for these data in PAUP v4.10b (Swofford 2001). Starting trees were formed by stepwise addition using a simple addition sequence with one tree held at each step. The branch-swapping algorithm was tree bisection reconnection (TBR). To adjust for multi-state characters being "overweighted" in the analysis, binary characters were weighted as 1.00 , those with 3 states as $2 / 3,4$ states as $2 / 4,5$ states as $2 / 5$ and so forth.

In the following phylogenetic taxonomy we apply the naming conventions proposed by de Queiroz (2007) and de Queiroz \& Gauthier (1990). The intent of this approach is to conserve widely used names and their meanings to the greatest extent possible while also precisely delimiting the nested sequence of evolutionary clades that encompass organic diversity. This approach allocates living species to a series of crown clades that together with their extinct stem lineages (and extinct side clades) comprise the total clade (defined as a branch-based taxon: all species more closely related to the common ancestor of the crown clade than to the common ancestor of the most closely related crown clade; Fig. 1). Crown clades feature node-based definitions that reference the last common ancestor of a pair of living species. This convention allows us to recognize distinctive living groups, such as the Tetrapoda, based on the numerous, uniquely shared characteristics that distinguish them from the closest relative among living organisms. At the same time this approach also allows us to classify, in a phylogenetically appropriate way, stem lineage species that had not yet acquired all the characteristics we typically think of as the defining properties of the crown group. Thus, the spectacular fossils of Tiktaalik roseae, may be in- 
cluded as a stem taxon within the Pan-Tetrapoda in recognition of its position in the evolutionary transition between the crown group Tetrapods and their aquatic ancestors.

The focus on living species provides an objective basis for separating crowns and stems, but is not applicable to entirely extinct clades like the graptoloids, which then are relegated to the status of a side branch on a stem lineage (in our case, as a side branch from the stem leading to living rhabdopleuran hemichordates). One might employ some other datum as a basis for defining crown clades among contemporary groups, but this again does not work well for a strongly unbalanced tree, the component clades of which have strongly asynchronous diversity histories. Thus, we employ here the strongly asymmetric structure of our consensus tree itself, combined with a commitment to retain the historical names to the fullest extent possible, as a means to apply de Queiroz' (2007) integrated naming conventions. Finally, this convention has the further benefit of reducing somewhat the number of unfamiliar names required to encompass the evolutionary history of a clade within a fully nested phylogenetic taxonomy.

In some instances all the species included in a particular crown clade in this analysis are exactly the same as those shown for the more inclusive total-clade, suggesting that the two names are redundant. This simply reflects the fact that we have not included species in our analysis that were members of the stem lineage. It does not mean that there were no stem species, or that these taxa are redundant - only that by chance (not knowing the precise tree structure in advance), we did not in these instances happen to include stem species.

\section{Results}

PAUP* retained 80 , equally most parsimonious trees with a tree length of $159+$ steps. Of those 80 , the 24 trees with the least amount of increase in tree length (20 steps) by the addition of an ordered stratigraphic character in MacClade, were used to compute a consensus tree.

We calculated 1,000 random trees with the same settings used to calculate the MPT's, resulting in a mean tree length of 232 steps. There were no random trees that approached the number of steps in the most parsimonious tree obtained from this data set. The probability of getting a tree of 159 steps at random is less than $1 / 1000$, or $p<0.001$, suggesting a strong phylogenetic signal in our data. The MPT's had a consistency index (CI) of 0.46 , a retention index (RI) of 0.64 , and a rescaled consistency index (RC) of 0.29 . A T-test for difference in mean retention index between proximal and distal characters indicates significantly more synapomorphy in proximal characters ( $\mathrm{p}<0.10$ ). Fig. 2 illustrates the 179-step, 50\% majority rule, consensus tree, which we consider to be the most reliable hypothesis of relationship available from these data.

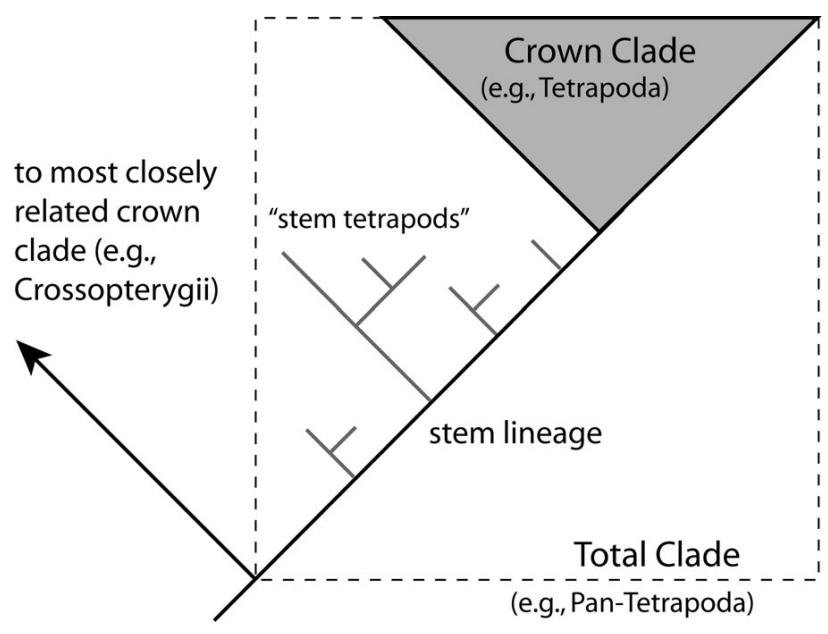

Figure 1. Conceptual diagram showing the relationship between crown clades (a group of living species descended from a common ancestor), their extinct stem lineage and the total clade that include both the stem and crown (see text for further discussion; modified from de Queiroz 2007).

Most notable in the structure of the tree is the formation of two major clades; one including species typically called sinograptids and sigmagraptines and another including the dichograptids, tetragraptids, glossograptids and more derived taxa. Dichograptid species are not nearly as resolved as some of the more derived groups: a major trichotomy obscures the pattern of nested common ancestry in that part of the tree. The other important feature is the sistergroup relations revealed between glossograptids (above node 9) and all more derived graptoloids (the Pan-Axonophora, arienigraptids and all their descendents, including diplograptids and monograptids) at node 10 . We employ this tree and its basic structure to construct the classification scheme presented in the following pages. Space limits do not allow us to present the full suite of synapomorphies across the tree, however we do present those associated with the nodes that are of particular interest for the definition of the taxa described below. Except for the apomorphy-based definition of the Graptoloida, however, the features that change at these points in the tree generally do not represent major structural or functional changes rather they are incremental modifications in a continuous series of adaptive transformations that resulted in the several distinctive crown groups.

\section{Systematic paleontology: A revised taxonomy for the Graptoloida}

\section{Subdivision Graptoloida Lapworth}

(in Hopkinson \& Lapworth, 1875, ex. Section Graptoloidea Lapworth) emended, Fortey \& Cooper, 1986

Definition. - The apomorphy-based Graptoloida is the first 


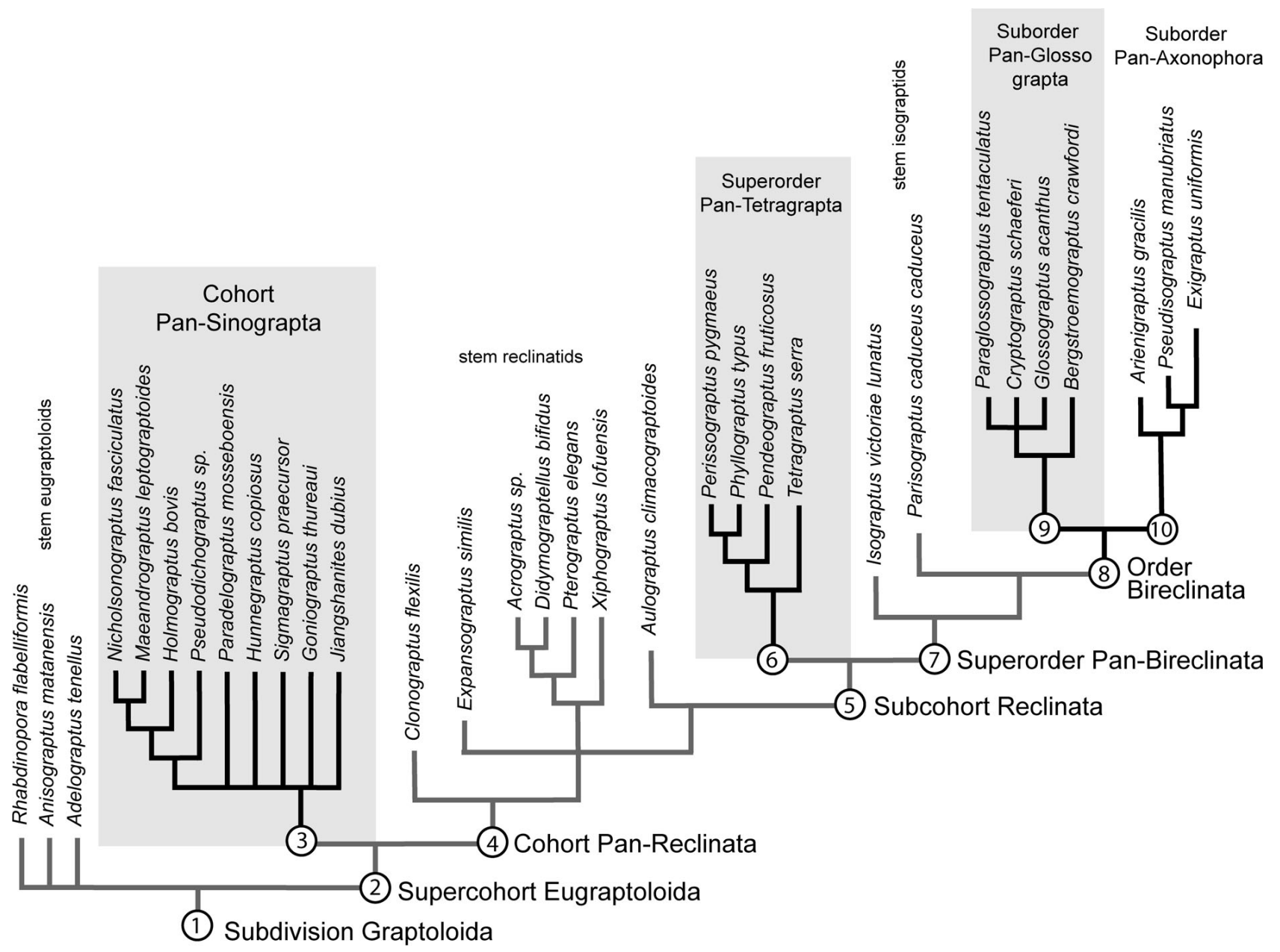

Figure 2. Recommended taxonomy of the Graptoloida, based on Carlucci (2008). Synapomorphies at major nodes indicated by numbers. 1 - nematophorous sicula, 2 - loss of bithecae on stipes, 3 - parallel-sided sicula, 4 - symmetrical crossing canals, 5 - acquisition of sicular and thecal rutellum, elongation of the sicula, 6 - quadriramous rhabdosome, 7 - isograptid symmetry, 8 - very long, slender sicula, 9 - monopleural rhabdosome, 10 - manubrium.

species to possess a nematophorous sicula with a free nema in the adult stage and all its descendents.

Remarks. - Fortey \& Cooper (1986) defined the Graptoloidea as a monophyletic clade by inclusion of all planktic, "nematophorous" graptolites within the clade, including the primitive, bithecae-bearing species traditionally regarded as the pelagic dendroids (Family Anisograptidae of Bulman 1950). We currently know relatively little about the development and proximal structure of dendroid graptolites and this limits our ability to understand the transformation from attached benthic graptolithines to the pelagic nematophorous graptolithines. Thus, we are unable to specify the sistergroup relations needed to define the Graptoloida as a total clade. If data that overcome this limitation become available, it may be possible to redefine the Graptoloida as a crown clade within a broader Pan-Graptoloida that includes the now poorly known steps and links planktic graptolites with the benthic antecedents.

The loss of bithecae among early graptoloids (Fig. 3A) appears to have been polyphyletic (Bulman 1960, 1970; Erdtmann 1982; Fortey \& Cooper 1986; Maletz \& Erdtmann 1987; Lindholm \& Maletz 1989). Although our analysis included only three anisograptids (Rhabdinopora, Anisograptus, Adelograptus), their position in our consensus tree is consistent with Fortey \& Cooper's interpretation of the anisograptids as a paraphyletic stem group to the more derived graptoloids. Very few relief specimens or isolated specimens of Upper Tremadocian to Lower Floian (Lower Ordovician) age exist to provide adequate documentation of the loss of bithecae in the anisograptids during the Tremadocian. In particular, the diverse Upper Tremadocian anisograptid faunas (Williams \& Stevens 1991, Lindholm 1991) could not be included in this analysis but, when better known, may provide important evi- 
dence for the origination of the early graptoloid clades (e.g. Pan-Reclinata nov. and Pan-Sinograpta nov.).

\section{Supercohort Eugraptoloida nov.}

Definition. - The clade Eugraptoloida nov. is the common ancestor of Nicholsonograptus fasciculatus and Exigraptus uniformis and all its descendents.

Remarks. - This crown clade encompasses all the species typically included among the traditional Graptoloidea sensu Bulman (1970) and comprises two main subclades, the Pan-Sinograpta and the Pan-Reclinata. Both differ in the symmetry of their proximal end and proportions of the sicula. As discussed further below, sicular bithecae persist in several lineages within the Eugraptoloida, but the origin of the group appears to be closely associated with the loss of bithecae in the stipes (synapomorphy 2, Fig. 2).

\section{Cohort Pan-Sinograpta nov.}

Definition. - The total clade Pan-Sinograpta nov. is defined as all species that share a more recent common ancestor with Nicholsonograptus fasciculatus than with Exigraptus uniformis. This definition specifies the left-side branch arising from the common ancestor represented by node 2 in Fig. 2.

Remarks. - In our analysis, the Pan-Sinograpta nov. is a sister taxon to the Pan-Reclinata nov (defined below). The differences are based upon the development and symmetry of the crossing canals (Fig. 3). The Pan-Sinograpta probably has roots close to the Tremadocian genus Paradelograptus (Fig. 3B), a genus including multiramous to two-stiped species with a highly asymmetrical proximal end (plesiomorphic character shared with the anisograptids; Fig. 3A, cf. Adelograptus). Paradelograptus species have a sicular bitheca (Jackson \& Lenz 2000), but bithecae have not been found along the stipes. The basal Sigmagraptidae (sensu Cooper \& Fortey 1982; not shown in Fig. 2) retain the asymmetry of the proximal end from the stem eugraptoloids ("anisograptids"), but place the slender, parallel-sided sicula vertically between the stipes (synapomorphy 3 in Fig. 2; see also Fig. 3C). The thecae are simple tubes, often undulating in derived forms and may possess rutellae and lateral apertural lappets.

\section{Subcohort Sinograpta Mu, 1957}

(ex. Family Sinograptidae Mu, 1957)

Definition. - The crown clade Sinograpta comprises the common ancestor of Nicholsonograptus fasciculatus and

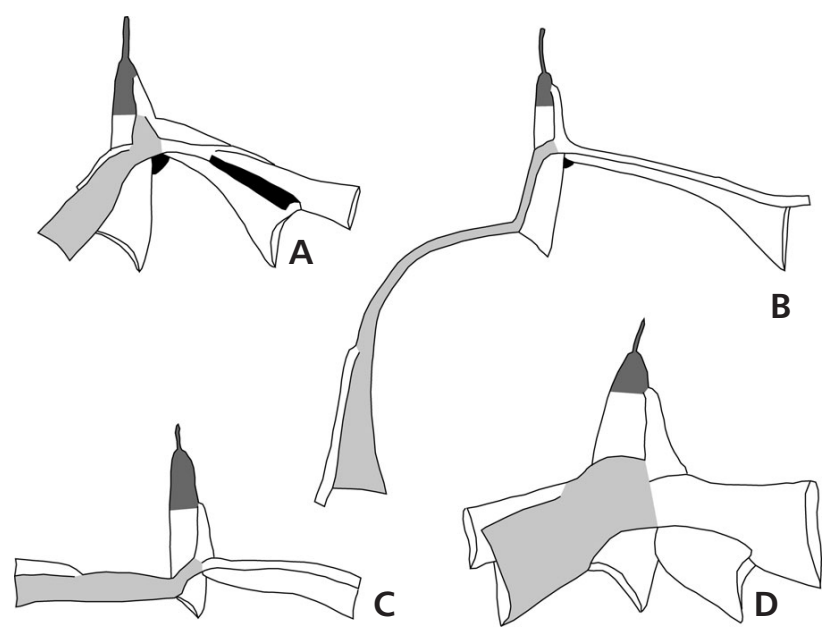

Figure 3. A - Adelograptus tenellus (Linnarsson, 1871) (based on Hutt 1974, fig. 6c), stem eugraptoloid. • B - Paradelograptus onubensis Erdtmann, Maletz \& Gutiérrez-Marco, 1987 (based on Maletz \& Egenhoff 2001, fig. 5h), Sinograpta. • C - Sigmagraptine sp. 1 (based on Maletz 2004b, fig. 6f), Sinograpta. • D - Didymograptellus nitidus Hall, 1858 (based on Maletz 2004b, fig. 2r), stem reclinatid. Dicalycal thecae and prosiculae indicated in light grey; bithecae in dark gray (A, B).

the first species with a slender sicula and parallel-sided prosicula (Fig. 3B, C) and all its descendents.

Remarks. - This taxon includes the species included by $\mathrm{Mu}$ (1957) in the Sinograptidae as well as those that Cooper \& Fortey (1982) and Fortey \& Cooper (1986) identified as the Sigmagraptidae. The taxon also encompasses all the members of the Pan-Sinograpta included in the present analysis. However, it is likely that among the late Tremadocian multiramous graptoloids there are species which, when better known, will emerge as members of the Pan-Sinograpta and link the crown group Sinograpta more precisely with their common ancestor at the root of the Eugraptoloida.

The present analysis does not provide sufficient resolution to examine the status of the widely used families Sinograptidae, Kinnegraptidae and Abrograptidae (e.g., Bulman 1970). Most probably this lack of resolution within the Sinograpta is due to the lack of information on proximal structure in many of the genera. A more detailed analysis of additional material preserved in relief or obtained in acid-etched samples will be necessary to resolve their relationships within the total clade Sinograpta.

\section{Cohort Pan-Reclinata nov.}

Definition. - The total clade Pan-Reclinata nov. comprises all species that share a more recent common ancestor with Exigraptus uniformis than with Nicholsonograptus fasciculatus. 
Remarks. - Members of the Pan-Reclinata can easily be recognized by their symmetrical proximal branching (synapomorphy 4, Fig. 2; see also Fig. 3D), which differs considerably from the often highly asymmetrical development in the Pan-Sinograpta and stem eugraptoloids (Fig. 3B, C). The clade is a sister clade to the PanSinograpta. The Pan-Reclinata includes graptolites that differ markedly among one another in stipe number and orientation. Our analysis displays low resolution within the stem lineage of the group, especially among the "dichograptids" of earlier taxonomies (see Bulman 1970). Little is known about the internal structure of the early stem reclinatids in particular. We included only two multiramous taxa (Clonograptus, Pterograptus) in our analysis, and these taxa exhibit very different modes of branch development. Colonies of Clonograptus employ the normal isograptid development to produce stipe dichotomies, whereas in Pterograptus specimens branching is achieved through cladia as a secondary way of producing a multiramous rhabdosome (Skwarko 1974, Maletz 1994a). Cladial branching also appears independently in several lineages within the Axonophora (e.g., dicranograptids Nemagraptus and Tangyagraptus and the monograptids Cyrtograptus and Linograptus).

\section{Subcohort Reclinata nov.}

Definition. - The crown clade Reclinata nov. is the common ancestor of Tetragraptus serra and Exigraptus uniformis and all its descendents.

Remarks. - The origin of the clade is closely associated with several synapomorphies at node 5 (Fig. 2), acquisition of a rutellum on the ventral side of the sicular aperture, serially homologous ventral projections on the proximal thecae (thecal rutellae), and a longer sicula than is common in preceding stem-reclinatids.

This clade includes two sister subclades: the relatively small Superorder Pan-Tetragrapta and the diverse PanBireclinata. The latter includes all the lineages that come to dominate Middle Ordovician and younger graptoloid faunas. The Reclinata have one or two first order stipes (as mentioned above, some derived species within the Axonophora secondarily acquire multiramous colonies by cladial branching), and most have reclined or scandent stipes (but horizontal and declined forms are present).

\section{Superorder Pan-Tetragrapta nov.}

Definition. - The total clade Pan-Tetragrapta nov. includes all species that have a more recent common ancestor with Tetragraptus serra than with Exigraptus uniformis.
Remarks. - All species of the Pan-Tetragrapta included in this analysis are also members of the crown group Tetragrapta. Stem lineage tetragraptids are poorly known.

\section{Order Tetragrapta Mu, 1950}

(ex. Tetragraptinae Mu, 1950)

Definition. - The crown-clade Tetragrapta is the common ancestor of Tetragraptus serra and the first species to have distal dicalycal thecae limited to th $3^{1}$ and th $3^{2}$, forming a quadriramous rhabdosome (synapomorphy 6, Fig. 2; see also Fig. 4B).

Remarks. - The Tetragrapta form a small, but successful clade that includes horizontal to declined, deflexed to reclined and scandent, quadriramous dichograptids. One or more of the multiramous taxa that occur on the stem lineage of the Reclinata in our current analysis may belong instead to the stem lineage of the Tetragrapta. Alternatively, the quadriserial form of the Tetragrapta may be a secondary acquisition of stipe dichotomies since all the immediate sister taxa among the stem reclinatids are two-stiped. Two main lineages can be differentiated within the Tetragrapta: 1) a group of declined to deflexed forms including Pendeograptus (Fig. 4A: two-stiped example) and its closest relative Corymbograptus (Maletz 1994b) and 2) the horizontal to reclined and scandent, tetragraptids (Tetragraptus, Fig. 4B, D) including the quadriserial Phyllograptus, Pseudophyllograptus and Pseudotrigonograptus.

The analysis places Perissograptus (Fig. 4C) within the Tetragrapta, in agreement with Fortey et al. (2005). The proximal end structure of Perissograptus pygmaeus (see Williams \& Stevens 1988) appears to us to resemble sinograptids such as Maeandrograptus (especially in the high placement of the crossing canals, Fig. 4E) more closely than Tetragraptus, but the current analysis suggests this represents homoplasy. Alternatively, our coding may have failed to fully capture the nuances of these shapes and the reclined condition of Perissograptus may have been independently attained from a sinograptid ancestor.

Fortey \& Cooper (1986) included the subfamily Tetragraptinae Mu (1950) in the Dichograptidae and differentiated the group based on the massive structure of the crossing canals on the reverse side of the rhabdosome (Fig. 4B, D). Their concept of the group differs in several respects from that suggested by our results. Fortey \& Cooper (1986) with some hesitance, placed Pseudotrigonograptus in its own family within their Glossograptacea, based on their interpretation of the symmetry of its proximal end. However, it appears not to possess isograptid symmetry as they suggested. In addition, Fortey \& Cooper (1986) included Phyllograptus and the Phyllograptidae within their suborder Virgellina. The three 

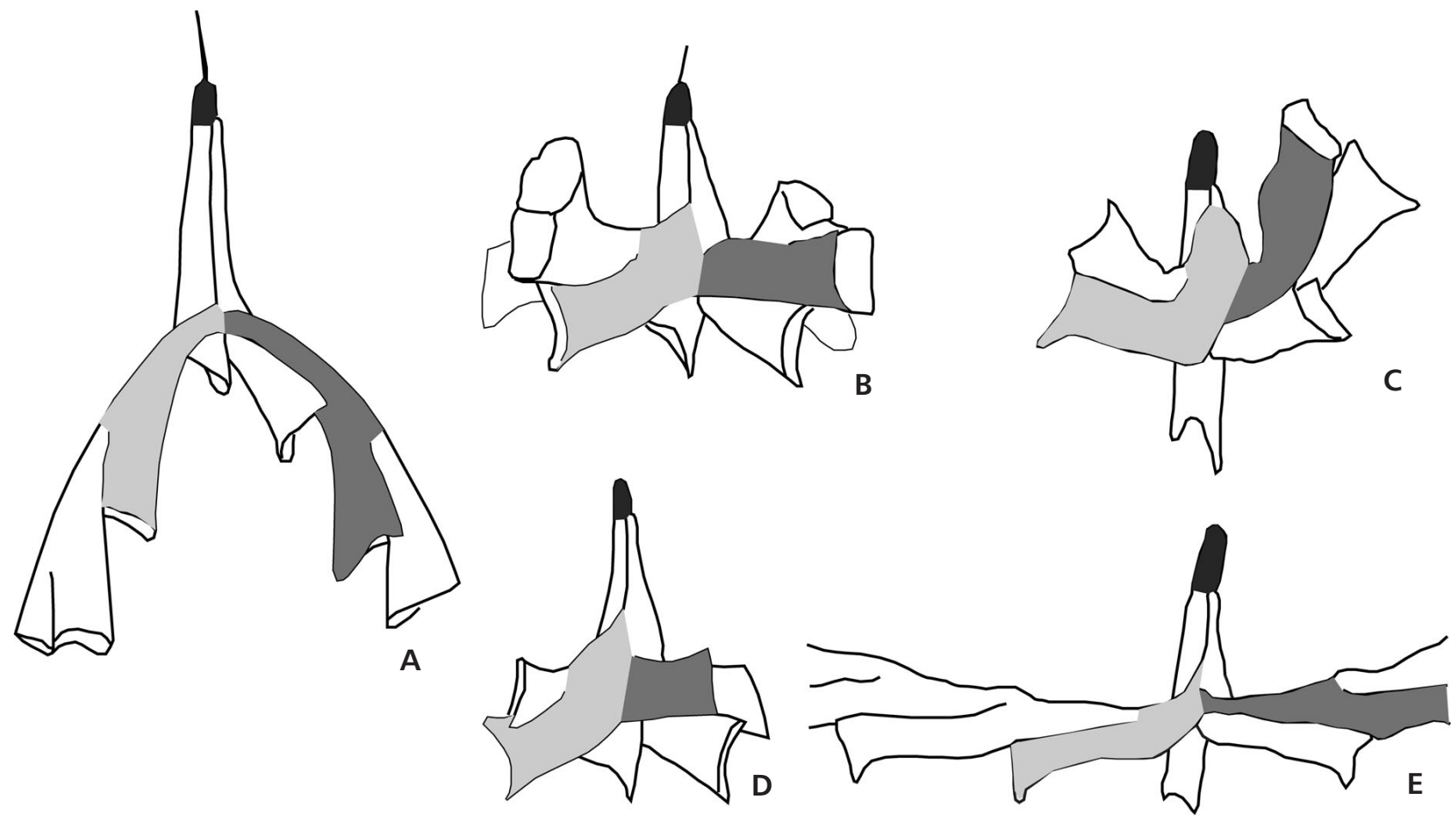

Figure 4. A - Pendeograptus fruticosus (Hall, 1858), two-stiped specimen (based on Maletz 2004b), Tetragrapta. • B - Tetragraptus serra (Brongniart, 1828), proximal end (based on Cooper \& Fortey 1982), Tetragrapta. $\bullet$ C - Perissograptus pygmaeus (Ruedemann, 1904), reconstruction based on GSC 82059 (Williams \& Stevens 1988, pl. 29, figs 13, 14), ?Tetragrapta. • D - Tetragraptus phyllograptoides triumphans Cooper \& Fortey, 1982 (based on Cooper \& Fortey 1982), Tetragrapta. • E - Maeandrograptus mobergi (Törnquist, 1901) (based on SGU specimen, Moberg collection, Killeröd, Scania), Pan-Sinograpta.

quadriserial genera Pseudophyllograptus, Phyllograptus and Pseudotrigonograptus appear to us to be closely related based on their rhabdosome development and are here included in the Tetragrapta. The genus Phyllograptus has a dorsal virgella, as do the "didymograptids" Xiphograptus, Yutagraptus and Pterograptus, but these taxa nest among the stem reclinatids in the consensus tree, indicating that the dorsal virgella originated independently in these taxa.

\section{Superorder Pan-Bireclinata nov.}

Definition. - The total clade Pan-Bireclinata nov. is all species that share a more recent common ancestor with Exigraptus uniformis than with Tetragraptus serra.

Remarks. - On present evidence, the origin of this clade appears to be the first species to acquire two reclined stipes that have an isograptid symmetry (synapomorphy 7, Fig. 2; see also Fig. 5E).

Isograptus species appear by their isograptid symmetry and simple thecal style (Fig. 5E) to form a paraphyletic stem to the Bireclinata. As Fortey \& Cooper (1986, p. 646) noted, the "acquisition of isograptid symmetry ... appears to be accompanied by a reclined attitude of stipes and to characterize a broad group..." Several recent analyses (Mitchell et al. 1995, Fortey et al. 2005) together with the present study clearly indicate that the stem group isograptids are ancestral to the derived diplograptids and their descendents (included here in the Axonophora, see below) and to the glossograptids. Contact between the dorsal side of the stipes first appears in Parisograptus and is retained in the crown-group Bireclinata and expressed as monopleural (glossograptids) and dipleural (axonophorans) scandent colony forms.

\section{Order Bireclinata nov.}

Definition. - The crown clade Bireclinata is the common ancestor of Glossograptus acanthus and Exigraptus uniformis and all its descendents.

Remarks. - The origin of the group appears to be closely associated with the acquisition of a characteristically long and narrow sicula exhibited by glossograptids and early axonophorans. Colonies of the great plurality of graptolites in the clade are scandent proximally or throughout. The Pan-Glossograpta retained isograptid symmetry while undergoing substantial modification in rhabdosome shape, 
whereas the second group of derived isograptids, the Pan-Axonophora, lost the isograptid symmetry and developed a dramatically modified proximal structure with a secondary maeandrograptid symmetry. The Pan-Glossograpta and the Pan-Axonophora independently, but nearly synchronously, developed biserial scandent rhabdosomes, and the ensuing adaptive radiation led to their dominance in all following graptoloid faunas. This event marks the base of the Darriwilian Stage in the revised international standard chronostratigraphy of the Ordovician System (Mitchell et al. 1997).

\section{Suborder Pan-Glossograpta nov.}

Definition. - The total clade Pan-Glossograpta nov. is all species more closely related to Glossograptus acanthus than to Exigraptus uniformis.

\section{Family Glossograptidae Jaanusson, 1960 \\ (ex. Glossograptida Jaanusson, 1960)}

Definition. - The crown clade Glossograptidae is the common ancestor of Glossograptus acanthus and the first species to have a monopleural arrangement of the stipes (synapomorphy 9, Fig. 2; see also Fig. 5B, C).

Remarks. - In addition to the characteristic pericalycal, monopleural colony structure of these biserial scandent graptolites, the origin of glossograptids also appears to be closely associated with the acquisition of a pair of prominent spines on the lateral margin of the sicular aperture. Bergstroemograptus crawfordi has an initially monopleural scandent arrangement of stipes (Finney \& Chen 1984) and appears therefore, to be the most primitive structurally of the true glossograptids although it is not the oldest species of the group. The enigmatic Skiagraptus may belong to the stem lineage of the Glossograptidae but its structural details are poorly known, as is the precise derivation of the group from within the Bireclinata. Thus, all the taxa in our analysis that belong to the Pan-Glossograpta are also members of this crown clade. Kalpinograptus exhibits monopleural development proximally, however the stipes diverge distally (Fig. 5C). This condition appears to be derived in this genus and was not a transitional state from the primitive reclined state.

Maletz \& Mitchell (1996) included the genus Isograptus in the Glossograptidae, and recognized a distinct paraphyletic family, the Arienigraptidae, that included Pseudisograptus, Arienigraptus, Exigraptus, and the ancestor of diplograptids, and was sister to the glossograptids (as in this analysis), but they retained both families within a broader (and again paraphyletic) Didymograptina. Al- though the phylogenetic structure we discovered here is similar in many respects to the results of that analysis, we prefer to avoid paraphyletic taxa and so recommend a somewhat different set of higher taxa and treat the arienigraptids as part of the stem lineage of the Infraorder Axonophora (see below).

\section{Suborder Pan-Axonophora nov.}

Definition. - The total clade Pan-Axonophora nov. is all species sharing a more recent common ancestor with Exigraptus uniformis than with Glossograptus acanthus.

Remarks. - The origin of this clade appears to be closely linked with the origin of two unique and distinctive features of the proximal structure: the manubrium and the left handed-origin of th $1^{2}$ from the obverse side th $1^{1}$ (synapomorphy 10, Fig. 2; see also Fig. 5A, D). The Pan-Axonophora includes the stem axonophorans Arienigraptus, Pseudisograptus, and Exigraptus ("arienigraptids" sensu Maletz \& Mitchell, 1996), plus the crown-clade Axonophora (defined below).

The manubrium appears to have originated with the common ancestor of the stem lineage axonophorans Arienigraptus and Pseudisograptus, among which it is a prominent feature (Cooper 1973, Cooper \& Ni 1986). The manubrium was retained in Exigraptus and, in a strongly reduced form, in some species referred to the biserial genus Undulograptus (Fig. 5A). Cladistic analysis of the Dichograptacea led Fortey \& Cooper (1986) to unite all virgella-bearing graptoloids as the suborder Virgellina. It is now clear, however, that the dorsal virgella in Xiphograptus and Phyllograptus is not homologous to the ventral virgella in diplograptids (Mitchell et al. 1995, Maletz 1998, Fortey et al. 2005). Accordingly, the need for the name Virgellina has disappeared except perhaps as an alternative for the Axonophora Frech, 1897, for which it would be a junior synonym. Since this use would require a radical redefinition of the original meaning of the Virgellina, we see no value in retaining the name.

\section{Infraorder Axonophora Frech, 1897}

Definition. - The crown clade Axonophora is the common ancestor of Diplograptus pristis and Monograptus priodon and all its descendents.

Remarks. - The origin of this clade is closely associated with the acquisition of a proximal structure based on four primordial thecae (sensu Mitchell, 1987) that is somewhat simplified relative to stem axonophorans with a reduced manubrium and five primordial thecae. 

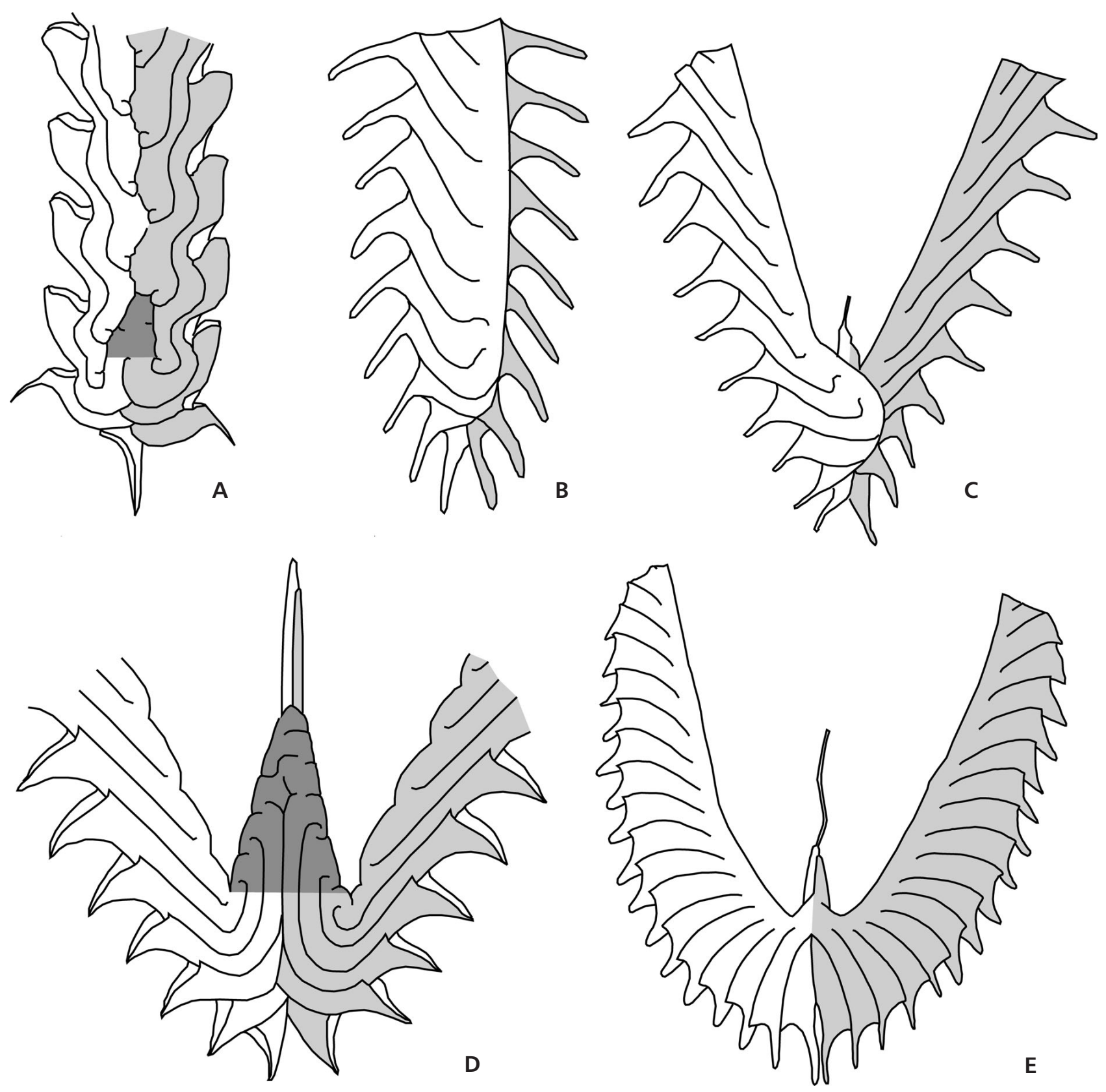

Figure 5. A. Undulograptus austrodentatus Harris \& Keble, 1932, biserial, dipleural rhabdosome with small manubrium (based on Mitchell et al. 1995), stem axonophoran. • B - Glossograptus sp., biserial, monopleural rhabdosome (based on Maletz \& Mitchell 1996, fig. 2). C - Kalpinograptus sp., two-stiped, initially scandent, monopleural rhabdosome (based on Maletz \& Mitchell 1996, fig. 2). - D - Pseudisograptus manubriatus ssp. two-stiped rhabdosome with manubrium (based on Mitchell et al. 1995). E - Isograptus sp. Killeröd, Scania (S. Sweden) (Maletz, unpublished). Stipe one shown in light grey in all specimens; manubrium in dark grey (in A, D).

Frech (1897) proposed the name Axonophora for scandent diplograptid and monograptid graptolites whose colonies grew upwards along the nema (which he referred to by the obsolete term "virgula"). Although later employed by Ruedemann (1947), Mu (1974), and others with a variety of slightly different meanings (see Rigby 1986 , for a review), Frech used the name in nearly exactly the same sense as we do here and even included
Dicranograptus and Dicellograptus in recognition of their partly axonophorous structure.

We employ the name Axonophora in a sense that corresponds very closely with the Order Diplograptoidea of Mitchell et al. (2007) - that is, to encompass the clades they referred to as the suborders Diplograptina and Monograptina. We place the base of the Axonophora slightly higher in their preferred tree, however, at the node that 


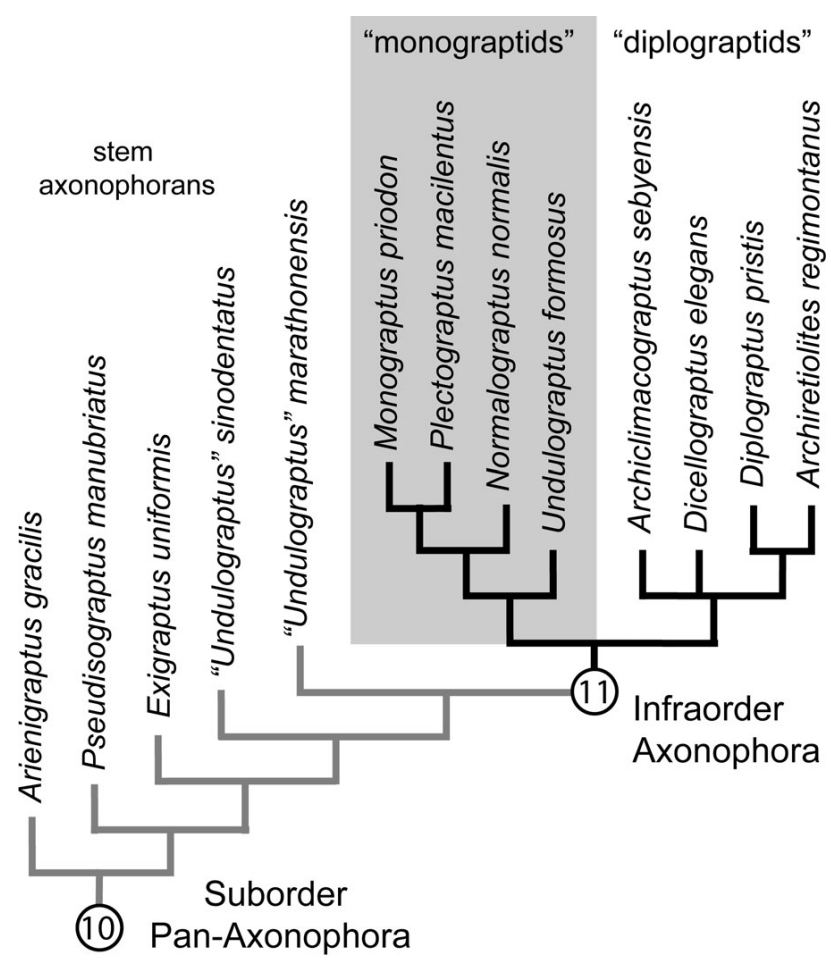

Figure 6. Relations within the Pan-Axonophora, with numbering of nodes discussed in text continued from those in Fig. 2. Synapomorphy 11: Simplified proximal structure with number of primordial thecae reduced from 5 to 4. "Monograptids" and "diplograptids" are informal total clades that comprise the Axonophora. Included species and the relations among them were drawn from analyses in Mitchell et al. (2007) and Melchin (1998) to provide a sense of the scope of these two clades.

unites these two clades and above the node that links them with "Undulograptus" marathonensis (Fig. 6; see also Fig. 1B of Mitchell et al. 2007) rather than at the common ancestor with "Undulograptus" sinodentatus. We advocate this change for several reasons. First, it utilizes the basal dichotomy within the "diplograptid" clade to form two holophyletic sister clades that encompass nearly all of the diversity of this crown group (Diplograptina+Monograptina sensu Bulman, 1970). Secondly, the diplograptids and monograptids have each traditionally been of comparable rank and the present choice avoids having to subsume one within the other, at odds with this tradition and their distinctive morphologies. Finally, this choice recognizes the stepwise acquisition of typical "diplograptid" characters that occurred along the axonophoran stem lineage and so avoids the need to establish an arbitrary boundary between what is and what is not fully a diplograptid. However, this choice does exclude some taxa from the Axonophora that have generally been regarded as diplograptids - in particular several species previously included in the genus Undulograptus (e.g., "Undulograptus" marathonensis through "U." sinodentatus in Mitchell et al. 2007). The precise definition of the sister clades that comprise the Axonophora requires discussion that is beyond the scope of this paper, and so we treat them informally in Fig. 6.

\section{References}

Brongniart, A. 1828. Histoire des végétaux fossiles. xii +488 pp., 171 pls. F.G. Levrault, Paris.

BULMAN, O.M.B. 1950. Graptolites from the Dictyonema Shales of Quebec. Quarterly Journal of the Geological Society of London 106(1), 63-99.

BULMAN, O.M.B. 1955. Graptolithina with section on Enteropneusta and Pterobranchia, xviii-V101. In MoORE, R.C. (ed.) Treatise on Invertebrate Paleontology, Part V. Geological Society of America \& University of Kansas Press, Lawrence.

BULMAN, O.M.B. 1963. The evolution and classification of the Graptoloidea. Quarterly Journal of the Geological Society of London 119(4), 401-418.

BulmAN, O.M.B. 1960. Some morphologically intermediate genera in graptolite phylogeny. $21^{\text {st }}$ International Geological Congress Norden Section 22, 65-70.

BULMAN, O.M.B. 1970. Graptolithina with sections on Enteropneusta and Pterobranchia, V5-V163. In TEICHERT, C. (ed.) Treatise on Invertebrate Paleontology, Part V. 163 pp. Geological Society of America \& University of Kansas Press, Boulder \& Lawrence.

CARLUCCI, J. 2008. Phylogenetic analysis, systematics, and evolution of early Ordovician graptolites. $111 \mathrm{pp}$. MS thesis, UB Buffalo, SUNY.

COOPER, R.A. 1973. Taxonomy and evolution of Isograptus Moberg in Australasia. Palaeontology 16(1), 45-115.

COOPER, R.A. \& FORTEY, R.A. 1982. The Ordovician graptolites of Spitsbergen. Bulletin of the British Museum of Natural History (Geology) 36(3), 157-302.

COOPER, R.A. \& FORTEY, R.A. 1983. Development of the graptoloid rhabdosome. Alcheringa 7(3-4), 201-221. DOI $10.1080 / 03115518308619621$

COOPER, R.A. \& NI, Y.-N. 1986. Taxonomy, phylogeny, and variability of Pseudisograptus Beavis. Palaeontology 29, 313-363.

DE QUEIROZ, K. 2007. Toward an integrated system of clade names. Systematic Biology 56, 956-974.

DO] $10.1080 / 10635150701656378$

DE QUEIROZ, K. \& GAUTHIER, J. 1990. Phylogeny as a central principle in taxonomy: phylogenetic definitions of taxon names. Systematic Zoology 39, 307-322.

DOI $10.2307 / 2992353$

ERDTMANN, B.-D. 1982. A reorganization and proposed phylogenetic classification of planktic Tremadoc (early Ordovician) dendroid graptolites. Norsk Geologisk Tidsskrift 62(2), 121-145.

Erdtmann, B.-D., Maletz, J. \& GutiéRreZ-Marco, J.C. 1987. The new early Ordovician (Hunneberg Stage) graptolite genus Paradelograptus (Kinnegraptidae), its phylogeny and biostratigraphy. Paläontologische Zeitschrift 61, 109-131.

FINNEY, S.C. \& CHEN, X. 1984. Bergstroemograptus n. gen. 
crawfordi (Harris) from the Ordovician of western Newfoundland. Canadian Journal of Earth Sciences 21, 1194-1199.

FORTEY, R.A. \& COOPER, R.A. 1986. A phylogenetic classification of the graptoloids. Palaeontology 29(4), 631-654.

FORTEY, R.A., ZHANG, Y.-D. \& MELLISH, C. 2005. The relationships of biserial graptolites. Palaeontology 48(6), 1241-1272. DOI 10.1111/j.1475-4983.2005.00510.x

FRECH, F. 1897. Lethaea geognostica oder Beschreibung und Abbildung für die Gebirgs-Formationen bezeichnendsten Versteinerungen, 544-684. Herausgegeben von einer Vereinigung von Palaeontologen., 1. Teil - Lethaea Palaeozoica. E. Schweizerbart'sche Verlagshandlung, Stuttgart.

HALL, J. 1858. Notes upon the genus Graptolithus, and description of some remarkable new forms from the shales of the Hudson River Group, discovered in the investigations of the Geological Survey of Canada, under the direction of Sir W. E. Logan, F.R.S. Canadian Naturalist/Geologist 3, 139-150, 161-177.

HALL, J. 1865. Graptolites of the Quebec Group: Figures and descriptions of Canadian organic remains, Decade II. $151 \mathrm{pp}$. Geological Survey of Canada, A.B. Dawson Brothers, Montreal.

HARRIS, W.J. \& KEBLE, R.A. 1932. Victorian graptolite zones, with correlations and descriptions of species. Proceedings of the Royal Society of Victoria 44, 25-48.

Hopkinson, J. \& LAPwORTH, C. 1875. Descriptions of the graptolites of the Arenig and Llandeilo rocks of St. David's. Quarterly Journal of the Geological Society of London 31, 631-672, pls 33-37.

HUTT, J.E. 1974. The development of Clonograptus tenellus and Adelograptus hunnebergensis. Lethaia 7(1), 79-92. DOI 10.1111/j.1502-3931.1974.tb00887.x

JAANUSSON, V. 1960. Graptoloids from the Ontikan and Viruan (Ordov.) Limestones of Estonia and Sweden. Bulletin of the Geological Institute of the University of Uppsala 38, 289-366.

JACKSON, D.E. \& LENZ, A.C. 2000. Some graptolites from the late Tremadoc and early Arenig of Yukon, Canada. Canadian Journal of Earth Sciences 37, 1177-1193. DOI 10.1139/cjes-37-8-1177

JAEGER, H. 1978. Entwicklungszüge (Trends) in der Evolution der Graptolithen. Schriftenreihe für Geologische Wissenschaften 10, 5-58.

LAPWORTH, C. 1873. On an improved classification of the Rhabdophora. Geological Magazine 10, 500-504, 555-560.

LinDHOLM, K. 1991. Ordovician graptolites from the early Hunneberg of southern Scandinavia. Palaeontology 34(2), 283-327.

LINDHOLM, K. \& MALETZ, J. 1989. Intraspecific variation and relationships of some Lower Ordovician species of the dichograptid, Clonograptus. Palaeontology 32(4), 711-743.

LINNARSSON, J.G.O. 1871. Om några försteningar från Sveriges och Norges Primordialzon. Öfversigt af Kongliga Vetenskaps-Akademiens Förhandlingar 6, 789-797.

MADDISON, D. \& MADDISON, W. 2005. MacClade v. 4.08. Sinauer Associates Inc.

MALETZ, J. 1994a. The rhabdosome architecture of Pterograptus
(Graptoloidea, Dichograptidae). Neues Jahrbuch für Geologie und Paläontologie, Abhandlungen 191, 345-356.

MaletZ, J. 1994b. Pendent Didymograptids (Graptoloidea, Dichograptina), 27-43. In CHEN, X., ERDTMANN, B.-D. \& NI, Y.-N. (eds) Graptolite Research Today. Nanjing University Press, Nanjing.

MALETZ, J. 1998. The evolution of the didymograptid Xiphograptus (Graptolithina, Didymograptinae), 215-217. In GUTIÉRREZ-MARCO, J.C. \& RÁBANO, I. (eds) Proceedings of the Sixth International Graptolite Conference of the GWG (IPA) and the SW Iberia Field Meeting 1998 of the International Subcommission on Silurian Stratigraphy (ICS-IUGS). Temas Geologico-Mineros ITGE 23.

MALETZ, J. 2004. Isolated Chewtonian (Lower Ordovician) graptolites from western Newfoundland. Paläontologische Zeitschrift 78, 173-187.

MaletZ, J. \& Egenhoff, S.O. 2001. The Late Tremadoc to early Arenig graptolite succession of southern Bolivia and their implications for a worldwide biozonation. Lethaia 34, 47-62. DOI 10.1080/002411601300068279

MaletZ, J. \& ERdTMAnN, B.-D. 1987. Adelograptus tenellus (Linnarsson 1871): Its astogenetic development and its stratigraphical and palaeogeographical distribution. Bulletin of the Geological Society of Denmark 35(3-4), 179-190.

MALETZ, J. \& MitChELL, C.E. 1996. Evolution and phylogenetic classification of the Glossograptidae and Arienigraptidae (Graptoloidea): New data and remaining questions. Journal of Paleontology 70, 641-655.

MELCHIN, M.J. 1998. Morphology and phylogeny of some early Silurian 'diplograptid' genera from Cornwallis Island, Arctic Canada. Palaeontology 41(2), 263-315.

MitCHELL, C.E. 1986. Morphometric studies of Climacograptus (Hall) and the phylogenetic significance of astogeny, 119-129. In HUGHES, C.P., RICKARDS, R.B. \& CHAPMAN, A.J. (eds) Palaeoecology and biostratigraphy of graptolites. Geological Society of London Special Publication 20.

Mitchell, C.E. 1987. Evolution and Phylogenetic Classification of the Diplograptacea. Palaeontology 30(2), 353-405.

MitChell, C.E., MALETZ, J. \& ZHANG, Y.-D. 1995. Evolutionary origins of the Diplograptina, 401-404. In COOPER, J.D., Droser, M.L. \& FinNeY, S.C. (eds) Ordovician Odyssey: Short Papers for the Seventh International Symposium on the Ordovician System. The Pacific Section Society for Sedimentary Geology (SEPM), Book 77, Fullerton.

Mitchell, C.E., Chen, X., BergströM, S.M., Zhang, Y.-D., WANG, Z.-H., WEBBY, B.D. \& FINNEY, S.C. 1997. Definition of a global stratotype for the Darriwilian Stage of the Ordovician System. Episodes 20(3), 158-166.

Mitchell, C.E., Goldman, D., Klosterman, S.L., MALETZ, J., SheETS, H. D. \& Melchin, M.J. 2007. Phylogeny of the Diplograptoidea. Acta Palaeontologica Sinica 46 (Supplement), 332-339.

MU, A.T. 1950. On the evolution and classification of graptolites. Geological Review 15, 171-183.

MU, A.T. 1957. Some new or little known graptolites from the Ningkuo Shale (Lower Ordovician) of Changshan, western 
Chekiang. Acta Palaeontologica Sinica 5(3), 369-437.

MU, A.T. 1974. Evolution, classification and distribution of Graptoloidea and Graptodendroids. Scientia Sinica 17(2), 227-238.

MU, A.T. 1987. Graptolite taxonomy and classification. Bulletin of the Geological Society of Denmark 35(3-4), 203-207.

RIGBY, J. 1986. A critique of graptolite classification, and a revision of the suborders Diplograptina and Monograptina, 1-12. In Hughes, C.P., Rickards, R.B. \& Chapman, A.J. (eds) Palaeoecology and biostratigraphy of graptolites. Geological Society of London Special Publication 20.

RuedemanN, R. 1904. Graptolites of New York, Part 1. Graptolites of the Lower beds. Memoirs of the New York State Museum of Natural History, Albany 7, 457-803.

RUEDEMANN, R. 1947. Graptolites of North America. Geological Society of America Memoir 19, 1-652.

SKWARKO, S.K. 1974. Some Ordovician graptolites from the Canning Basin, western Australia. 2: Graptolites from the Goldwyer No. 1 well. Bulletin of the Bureau of Mineral Resources, Geology and Geophysics of Australia 150, 43-56.

Strait, D., Moniz, M. \& Strait, P. 1996. Finite Mixture Coding: A new approach to coding continuous characters. Systematic Biology 45(1), 67-78. DOl 10.2307/2413512

SWOFFORD, D.L. 2001. PAUP*: Phylogenetic analysis using par- simony (* and other methods), version 4.0b8. Sinauer Associates, Sunderland Massachusetts.

TÖRNQUIST, S.V. 1901. Researches into the Graptolites of the Lower Zones of the Scanian and Vestrogothian Phyllo-Tetragraptus beds 1. Lunds Universitets Arsskrift 37, 2(5), 1-26, 3 pls.

URBANEK, A. 1960. An attempt at biological interpretation of evolutionary changes in graptolite colonies. Acta Palaeontologica Polonica 5, 127-234.

URBANEK, A. 1973. Organization and evolution of graptolite colonies, 441-514. In BOARDMAN, R.S., CHEETHAM, A.H. \& OLIVER, W.A. (eds) Animal Colonies Development and function through time. Dowden, Hutchinson \& Roiss, Inc., Stroudsburg, PA.

URBANEK, A. 2004. Morphogenetic gradients in graptolites and bryozoans. Acta Palaeontologica Polonica 49(4), 485-504.

WiLliams, S.H. \& STEVENS, R.K. 1988. Early Ordovician (Arenig) graptolites of the Cow Head Group, western Newfoundland, Canada. Palaeontographica Canadiana 5, 1-164.

WiLliams, S.H. \& STEVENS, R.K. 1991. Late Tremadoc graptolites from western Newfoundland. Palaeontology 34(1), $1-47$.

YU, J.-H. \& FANG, Y.-T. 1979. On the classification of graptoloids. Acta Palaeontologica Sinica 18(5), 435-442.

\section{Appendix}

Table 1. List of characters used in the analysis and their corresponding states. The $48^{\text {th }}$ character was added post-analysis, and was used for picking among most parsimonious trees. All characters treated as unordered except those marked *, which are ordered.

Prosicula:

1. Conus shape: expanding (0), parallel sided (1).

2. Float structures: absent (0), present (1).

3. Prosicular width: proportionally narrow (0), proportionally wide (1).

4. Prosicular length: proportionally short (0), proportionally long (1).

Metasicula:

5. Virgella: absent (0), dorsal (1), ventral (2).

6. Sicular rutellum: absent (0), normal (1), lanceolate (2).

7. Sicular aperture: dorsal and ventral sides free (0), ventral free (1), none free (2).

8. Second rutellum: absent (0), present (1).

9. Sicular shape: straight (0), bent (1).

10. Metasicular shape: expanding (0), parallel-sided (1).

11. Sicula aperture width: $(0)<0.17 \mathrm{~mm}(1), 0.17-0.29 \mathrm{~mm}(2)$, $0.29-0.49 \mathrm{~mm},(3)>0.49 \mathrm{~mm}$.

12. Paired apertural spines: absent (0), present (1).

\section{Rhabdosome:}

13. *Stipe attitude: pendent (0), declined (1), horizontal (2), reclined (3). scandent (4).

14. Branching: dichotomous (0), cladial (1).

15. Branching: primarily progressive (0), primarily monoprogressive (1).

16. Branching pattern: regular (0), irregular (1).

17. Thecal overlap: uniform (0), increasing (1).

18. Periderm reduction: normal periderm (0), reduced (1), lacking (2).

19. Distal dicalycal thecae: separated by 1 monocalycal (0), irregular (1), none (2).

20. Dissipiments: absent (0), present (1).

21. Number of distal dicalycal thecae: none (0), one (1), two (2), (3) unlimited (multiramous).

22. Paired rhabdosomal spines: absent (0), present (1).

23. *Maximum number of stipes: one (0), two (1), four (2), more than four (3).

Thecal Morphology:

24. Lateral apertural lappets: absent (0), present (1).

25. Thecal rutellum/denticle: absent (0), present (1).

26 . Thecal form: simple tube/gently curved ventrally (0), slightly undulating (1), sigmoid (2), geniculate (3).

27. Prothecal folds: absent (0), sigmagraptine type (1), pseudisograptid type (2).

28. Paired thecal apertural spines: absent (0), present (1).

29. Lacinia: absent (0), present (1).

Proximal Development:

30. Position of first dicalycal theca: $t h 1^{2}(0)$, th $1^{1}(1)$, no dicalycal theca (2).

31. Direction of prothecal growth of th $1^{1}$ : downwards (0), upwards directed (1). 
32. Position of bithecae along stipes: absent (0), alternating (1), irregular (2).

33. Sicular bitheca: absent (0), present (1).

34. Symmetry of proximal end: isograptid (0), maeandrograptid (1).

35. Number of proximal dicalycal thecae: $0(0), 1$ (1), 2 (2), 3 (3).

36. Development mode: dextral (0), dextral and sinistral (1).

37. Proximal branching style: symmetrical (0), asymmetrical (1), second stipe lost (2).

38. *Origin of th $1^{1}$ : in prosicula (0), in upper metasicula (1), in lower metasicula (2).

39. Sicula length: $<1.6 \mathrm{~mm}(0), 1.9-2.3 \mathrm{~mm}(1), 2.3-5.0 \mathrm{~mm}(2)$, $>5 \mathrm{~mm}(3)$.

40. Sicula length/width ratio: $2.9-5.0 \mathrm{~mm}(0), 5.0-7.6 \mathrm{~mm}(1)$, $>7.6 \mathrm{~mm} \mathrm{(2).}$
41. Direction of growth of th $1^{2}$ : downwards (0), upwards (1).

42. Rhabdosome development: monopleural (0), dipleural (1), unconnected stipes (2).

43. Manubrium: absent (0), present (1).

44. Arienigraptid suture: absent (0), present (1).

45. Glossograptid bulge: absent (0), present (1).

46. Proximal structure: platycalycal (0), pericalycal (1), plaited (2).

47. Proximal dorsal stipe contact: absent (0), present (1)

48. *Stratigraphy (in MY): 487.5-489.5 (0), 485.5-487.5 (1),

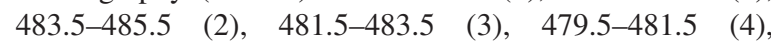

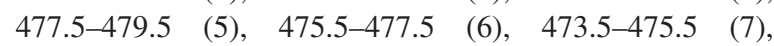
471.5-473.5 (8), 469.5-471.5 (9), 467.5-469.5 (10), 465.5-467.5 (11), 463.5-465.5 (12).

Table 2. Character matrix for cladistics analysis. A question mark (?) indicates missing data. Character 48, which has more than nine states, is coded with letters in alphabetical order following state 9 .

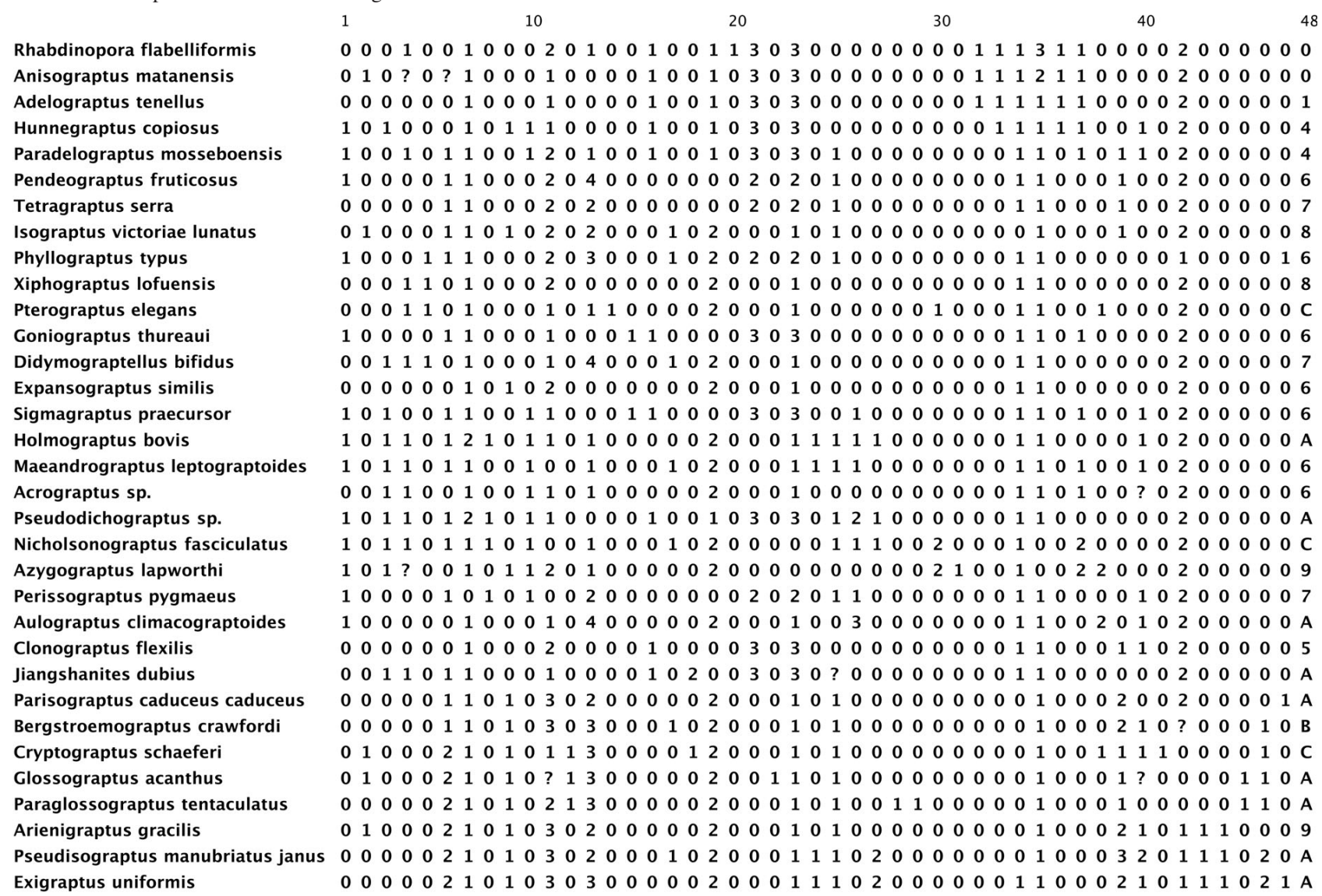

